九州大学学術情報リポジトリ

Kyushu University Institutional Repository

\title{
Dependency of shallow landslides on geometric parameters and its potentiality.
}

Majtan, Stefan

Laboratory of Soil and Water Conservation, Faculty of Agriculture, Kyushu University

Omura, Hiroshi

Laboratory of Soil and Water Conservation, Faculty of Agriculture, Kyushu University

Joshi, Jagannath

Laboratory of Soil and Water Conservation, Faculty of Agriculture, Kyushu University

https://doi.org/10.5109/24345

出版情報：九州大学大学院農学研究院紀要. 44 (3/4)，pp.445-453，2000-02. Kyushu University バージョン：

権利関係 : 
J. Fac. Agr., Kyushu IIniv., 44 (3·1), 445-453 (200)(0)

\title{
Dependency of shallow landslides on geometric parameters and its potentiality.
}

\author{
Stefan Majtán, Hiroshi Omura and Jagannath Joshi \\ Laboratory of Soil and Water Conservation, Faculty of Agriculture, \\ Kyushu University, Fukuoka 812-8581 Japan \\ (Received September 28, 1999 and accepted November 5, 1999)
}

\begin{abstract}
The study of shallow landslides is very imbortant from many points of view, especially recently, when urban development rich up to foot of mountain slope, where most of slope movernents occur. Every year, thousands of pcople are killed by landslides, therefore the monitoring of old slope movements as well as predict a suitable area for their development become today one of the most important task for scientists. The authors expect the cxample from recreation area Aburayama in Fuknoka districl could give any suggestion for solving and prediction of similarly problems in the short future.
\end{abstract}

\section{INTRODLCTION}

In June 1999, extensive and heavy rains triggered the occurrence of many shallow landslides in Kyushu and Chugoku region of Japan. The most damaged area in Fukuoka district was recreation area Aburayama, located in south direction from Fukuoka city (Fig. 1.), where 26 landslides occurred. Most of these landslides are situated in cutting respective filling part of slope along roads. For calculations of geometric parameters were used data from digital Suuchichizu, which do not reflected artificial intervention to the natural condition. We tried to find the relationship between geometric parameters of study area under natural condition and spatial distribution of landslides as well as to find the cause development of landslides. Also, we tricd to chalk out the areas with higher potentiality for development of landslides.

By reconnoiter of study area location of landslides and some basic characteristics have been recorded. As mentioned above, the most of landslides are located in filling and cutting parts of slope along the road. For the calculation of geometric parameters, these datid were insufficient because the data set was limited by number of landslides and the data do not reflected parameters under natural condition, but they are represent only small local area.

Key words: morphometric analysis, shallow landslides, calculation of geometric parameters, probability

\section{MATERIALS AND METHODS}

\section{Surface geometry analysis}

Geometric analysis is to analyze a spatial distribution of value of geometric parametors and also analysis of properties and spatial differentiation of georclief as a whole (Krcho, 1990; Mitášová, Hofierka 1993). 


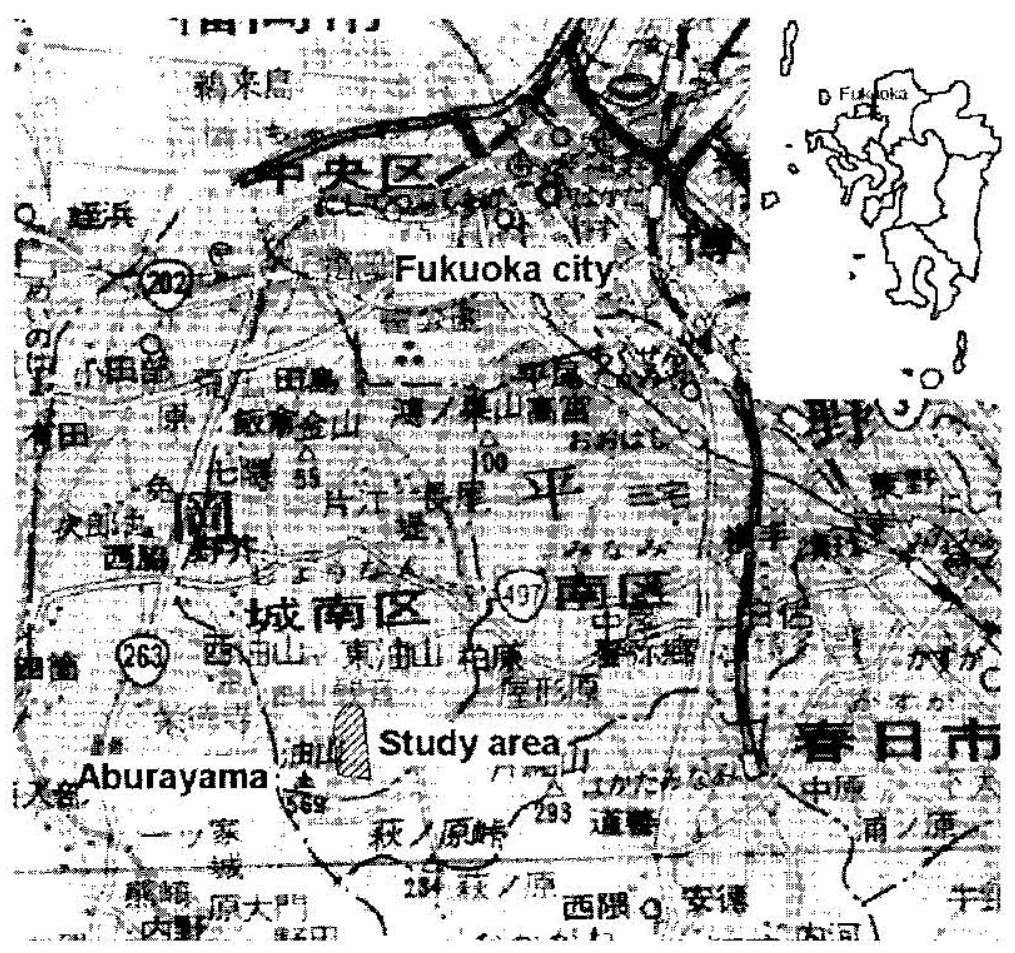

Fig. 1. Location of recreation area of Aburayama in Fukuoka district.

Before deriving mathematical expression for geometric parameters, we can definite partial derivation as follow:

$$
f_{s}=\frac{\partial z}{\partial x} ; f_{y}=\frac{\partial z}{\partial y}
$$

The calculation of geometric parameters in the detail we can find in the works Krcho, (1990); Mitášová, Hofierka, (1993). For clcarly understanding of mathematical expression, we can consider part of relief, where the geoid is sufficiently flat, that means it represents a plane. On this plane we can choose Cartesian coordinate system $\langle 0, i, j$, $k>$, where $i, j, k$ are unit vectors in direction of $x, y, z$ axis respectively. For each point of relief we are able to give a value of altitude $z$, in direction of the normal vector $\mathrm{N}$ (Fig. 2).

\section{Slope and aspect analysis}

The dip slope angle $\gamma_{\mathrm{N}}$ as well as aspect angle $\alpha_{\mathrm{N}}$ are calculated from gradient elevation array as follow (Krcho, 1993).

$$
\nabla f=f_{r}^{i}+f_{y}{ }^{3}
$$

Vector gradient $f$ has an orientation in the direction of normal vector to contour line 


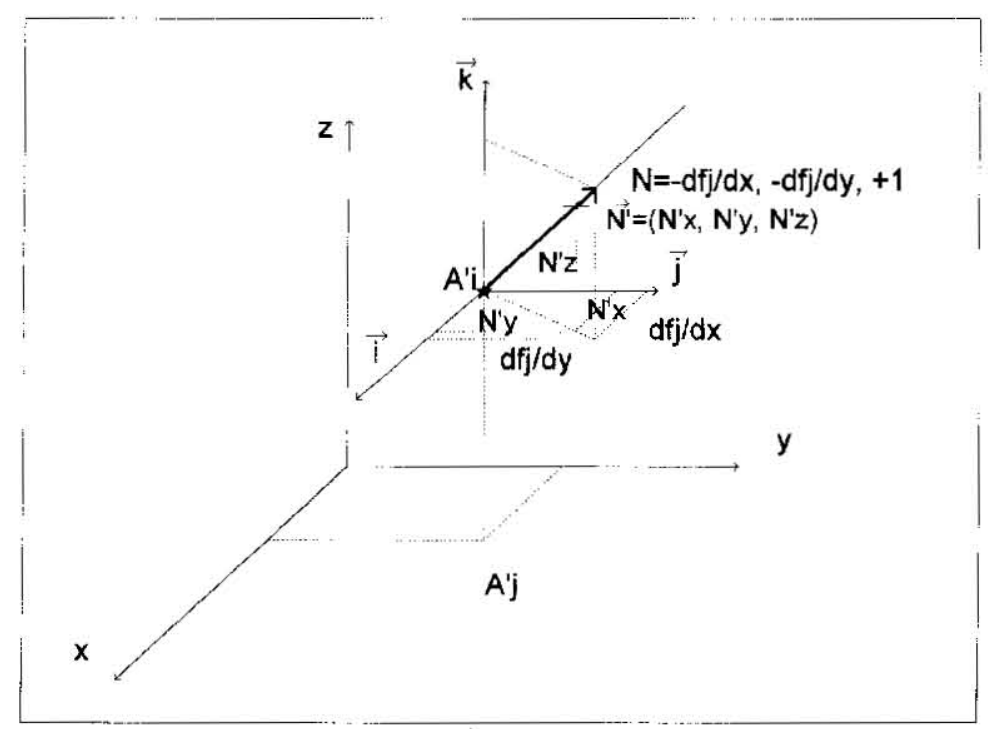

Fig. 2. Definition of normal vector $\mathrm{N}$ and implementation of Cartesian coordinate system $\langle 0, \mathrm{i}, \mathrm{j}, \mathrm{k}\rangle$, where $\mathrm{i}, \mathrm{j}, \mathrm{k}$ are unit vectors in direction to axes $\mathrm{x}, \mathrm{y}$ and $\mathrm{z}$ respectively. (taken from Krcho, 1990).

in each point of scalar field (Krcho, 1990). It has an absolute value in the corresponding point:

$$
\nabla f=\tan \gamma_{N}=\sqrt{f_{x}^{2}+f_{y}^{2}}
$$

where from

$$
\gamma_{x}=\arctan \sqrt{f_{x}^{2}+f_{y}^{2}}
$$

where $\gamma_{\mathrm{A}}$ is a dip slope angle.

We can consider the direction of normal vector to contour lines with the respect to sidclong decreasing scalar vector. The direction of this vector can be expressed as:

$$
\tan \alpha_{N}=\frac{-f_{y}}{-f_{x}}
$$

where from

$$
\alpha_{N}=\arctan \frac{-f_{y}}{-f_{x}}
$$

where $\alpha_{\mathrm{v}}$ is an aspect angle of vector gradient $f$ and also operative orientation of georelief to cardinal points. 


\section{RESULT AND DISCUSSION}

\section{Geometric parameters}

In the given area geometric parameters were calculated, then compared with spatial distribution of landslides. As source data have been taken from Sunchichizu with size of mesh 50 in published by Japan Geographic Institute.

As mentioned above, data were provided from Suuchichizu. The spatial distribution of data was equally distributed, with distance 2.25 " in $\mathrm{x}$-axis and $1.5 \mathrm{p}$ in $\mathrm{y}$-axis, respectively. Original data were transferred to ASCII file format $x, y, z$. The digital terrain model of study area was computed from 2014 data points using interpolation with regularized spline. The detail process of interpolation by regularized spline with tension is in works Mitášová, Mitáš (1993), Mitášová, Hoficrka (1993). Values of elevation, slope, aspect are computed in $97 \times 167$ grid cells, what means grid unit size $10 \times 10 \mathrm{~m}$ for the whole study area.

\section{Slope and aspect analysis}

Slope angle $\gamma_{\mathrm{N}}$ is calculated in degrees from $0^{\circ}$ (horizontal plane) to $90^{\circ}$ (vertical uphili) at every unit cell on our selected grid. For the location of landslides, a centroid of

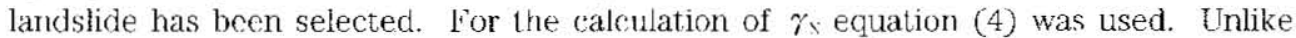
slope analysis, an aspect analysis provides as with direction of the slope angle $\gamma_{v}$ at each grid cell. In other words, this operation defines the direction in which water would flow over the surface. Aspect angle values $\alpha_{v}$ are reported in degrees, where $360^{\circ}$ due to East and $90^{\circ}$ due to North respectively. Aspect angle $\alpha$ was calculated from equation (6).

The altitude in the study area ranges between 111 and $496 \mathrm{~m}$ over the sea level respectively. This range was reclassificated to the six categories with step 50 elevation meters. That means, cach category represents area with different rank of elevation. In case of slope layer, the inclination floated between $0^{\circ}$ up to $44^{\circ}$. Also this laycr was reclassificated to the eight categories with step $5^{\circ}$. Values of aspect layer were reclassificated to the eight categories according to the cardinal points. The detail categories of individual layer shows Table 1. For the aggregation of landslides by region in individual layers, layers were overlaid in respect to elevation, slope and aspect with landslides. Then landslides were inspected for corresponding value of elevation, slope

Table 1. Chosen range categories in individual layers.

\begin{tabular}{clcc}
\hline Calegories & Elevation & Slope & Aspect \\
\cline { 1 - 3 } 1 & $<150$ & $<5$ & East \\
2 & $150-200$ & $5-10$ & East-North \\
3 & $200-250$ & $10-15$ & North \\
4 & $250-300$ & $15-20$ & North-West \\
5 & $300-350$ & $20-25$ & West \\
6 & $350-400$ & $25-30$ & West-South \\
7 & & $30-35$ & Sonth \\
8 & & $>40$ & South-East \\
\hline
\end{tabular}





a. Frcquency of landslides

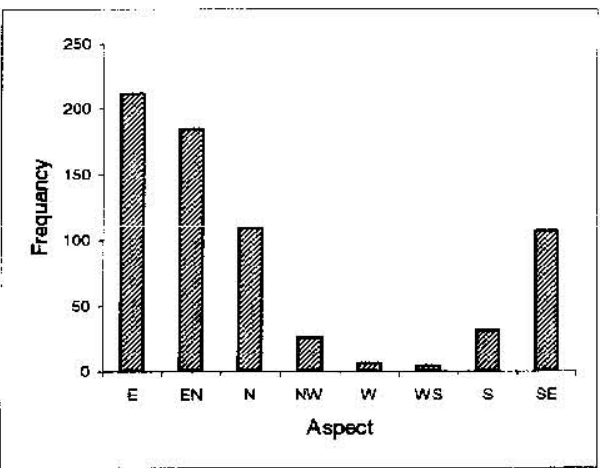

b. Frequency of road

Fig. 3. Frequency of landslides and road's inspected points from elevation, slope and aspect points of view. 
and aspect respectively. The spatial distribution of landslides with respect to elevation, slope and aspect in individual categories is shown in Fig. 3a. In the rank from $250 \mathrm{~m}$ to $350 \mathrm{~m}$ more than $60 \%$ of all landslides are concentrated. Unlike elevation frequency, the distribution of landslides with respect $t 0$ slope seems as random one. The most of landslides are concentrated on slope with inclination ranges from $10^{\circ}-15^{\circ}$ and from $20^{\circ}-25^{\circ}$. It represents more than $40 \%$. The aspect analysis is corresponding with natural location of recreation area Aburayama, which is located on the eastern side of Mt. Aburayama.

For the main purpose, to find the cause of landslides same analysis were done with line of road. For this purpose, the whole length of road, $6.81 \mathrm{~km}$, was inspcctod in each 10 meters for elevation, slope and aspect values. We got 681 inspected points, which covered the whole length of line roads. Also these points were overlaid and inspected over the elevation, slope and aspect layers. Points were aggregated to the same range and from same point of view as landslides (Tab. 1.). Thal means, elevation values of inspected points were aggregated to the six, slope values to the eight and aspect values also to the eight calegories. Figure 3b. shows spatial frequency of road's points from traced points of view. The percentual representation of individual ranges of elevation, slope and aspect respectively calculated from inspected points of road and from landslides respectively is shown in Tab. 2. The data were postprocessed by regression analysis as shown in Fig. 4. The figure shows clearly linear dependency between percent of landslides and inspected points of line road in all traced aspects. It means the landslides are equally distributed along the road's sides. Pcrcentual number of landslides and line of road from elevation point of view has the correlation coefficient. 0.923 and 0.844 from slope point of view, which are significant at 1\% level (Ishikawa, 1964) and from aspect point of view 0.823 , which is significant at $5 \%$ level. Shortly we can say that the main cause of occurrence of landslides is anthropogenous effect to the natural condition. The heavy rainfall scems as sccondary factor and its function was only as trigger which starts slope movements.

Table 2. shows percentual representation of landslides and road in individual ranges of elevation, slope and aspect respectively.

\begin{tabular}{|c|c|c|c|c|c|c|c|c|}
\hline & Elevation & & & Slope & & & Aspect. & \\
\hline Altitude $[\mathrm{m}]$ & Landslides [\%] & Roads $[\%]$ & Inclination $\left[^{\circ}\right.$ & ] Landslides [\%] & Roads $[\%]$ & Aspect & Landslides [\%] & Roads $[\%]$ \\
\hline $100-150$ & 3.85 & 0.88 & $<5$ & 3.85 & 6.18 & East & 30.77 & 31.13 \\
\hline $150-200$ & 7.69 & 12.33 & $5-10$ & 15.38 & 16.74 & East-North & 26.92 & 27.17 \\
\hline $200-250$ & 7.69 & 11.01 & $10-15$ & 23.08 & 24.67 & North & 0.00 & 16.15 \\
\hline $250-300$ & 34.62 & 38.03 & $15-20$ & 15.39 & 21.59 & North-West & 3.85 & 3.81 \\
\hline $300-350$ & 34.62 & 24.96 & $20-25$ & 19.23 & 15.12 & West & 3.85 & 0.88 \\
\hline $350-400$ & 11.54 & 12.78 & $25-30$ & 7.69 & 8.22 & West-South & 0.00 & 0.59 \\
\hline & & & $30-35$ & 3.85 & 4.26 & South & 7.69 & 4.55 \\
\hline & & & $35-40$ & 11.54 & 3.23 & South-East & 26.92 & 15.71 \\
\hline Corrclation & coefficient & 0.923 & Correlation & coefficient & 0.844 & Correlation & coefficient & 0.823 \\
\hline
\end{tabular}




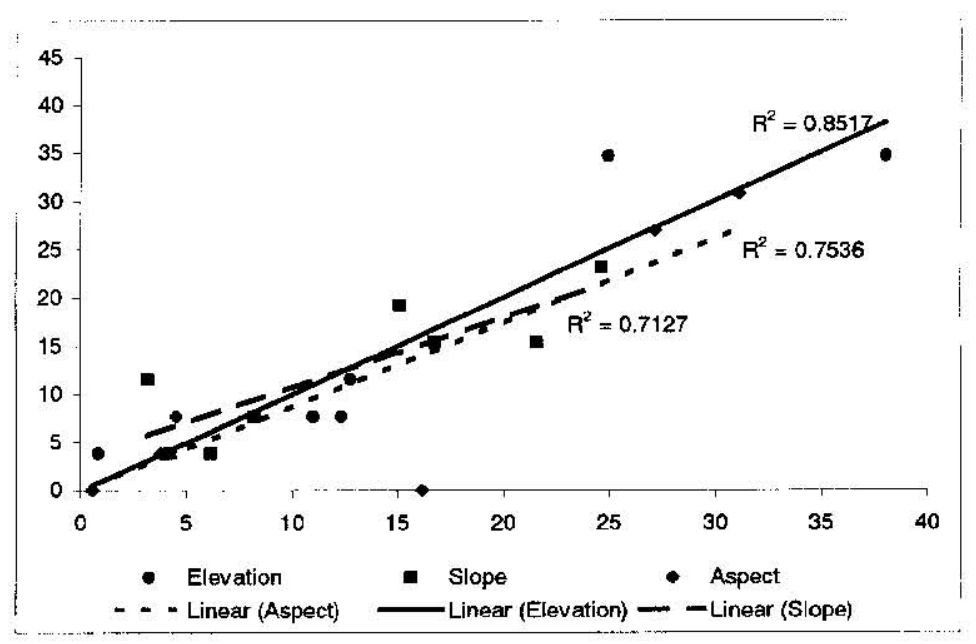

Fig. 4. Regression analysis of percentual representation of landslides and road in inctividual rarıses of elevation, slope and aspect respectivcly.

\section{Probability analysis}

In order to create a special map of potentiality area for occurrence of shallow landslides, we started from reclassificated layers of elevation, slope and aspect as we used in previous analysis. So, we had six regions in elevation layer, eight in slope layer and also eight one in aspect layer. After that, we calculated how many landslides exist in individual region from elevation, slope and aspect point of view. In these regions probability was calculated by an equation ( 7 )

$$
P_{S i} \frac{n_{S ;}}{N}
$$

where $\mathrm{P}_{\mathrm{si}}$ is probability in ,i“ region of "S" layer, $\mathrm{n}_{\mathrm{si}}$ is number of landisides in ,i“ region of "S" layer and $\mathrm{N}$ is total number of landslides. Then the value of probability $\mathrm{P}_{\mathrm{Si}}$ was added to the each grid cell, which it fall in region ,i" and layer "S".

These additional layers, which expressed the information about probability of region, were overlaid into one layer. The representative value of occurrence probability of landslides in each grid cell was calculated as the average of individual probabilitics in cach grid coll. For calculation equation (8) was used

$$
P_{i} \frac{\sum P_{S i}}{n_{S}}
$$

where $P_{i}$ is probability occurrence of landslides in ,i" grid cell, $\Sigma P_{\mathrm{si}}$ is sum of probabilities from elevation, slope and aspect layers respectively in , ,i“ grid cell and $n_{s}$ is number of probabilities.

On the basis of these calculations, the potentiality map on occurrence of landslides 
was created. This map is based on an uniformity area. That means we considered that calculated probability in individual range is characteristic for the whole study area, which is representing this range. The occurrence probability of landslides ranges from 0.0128 to 0.2948 . This range was divided into three categories, which are less than 0.1 , from 0.11 up to 0.2 and more than 0.2 . These categories indicate low, medium and high area of potentiality respectively. By this analysis $13.2 \%$ of study area is classified into low, $48.5 \%$ into medium and $38.3 \%$ into high potentiality range. The result is shown in Fig. 5.

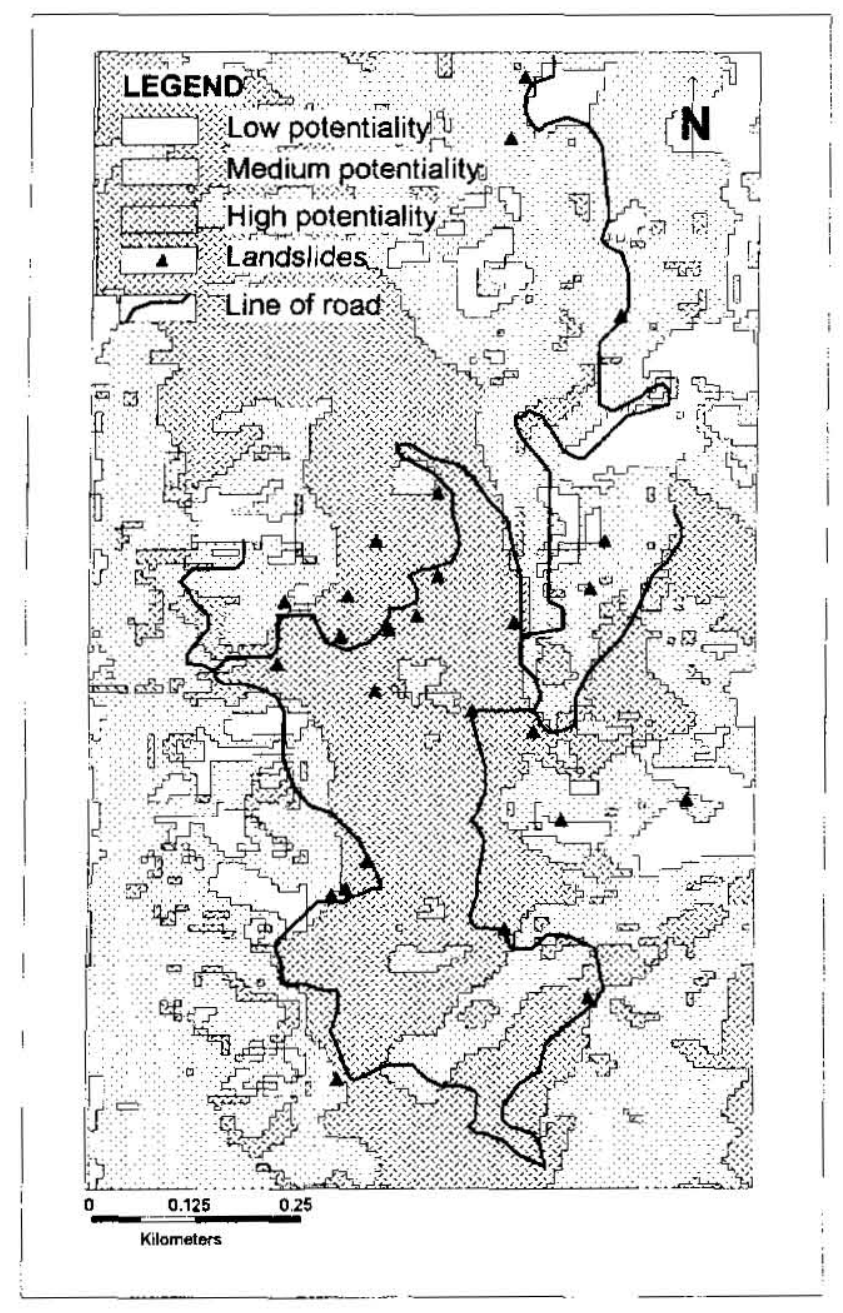

Fig. 5. Map of probability occurrence of landslides in recreation area Aburayamia in Fukuoka district basis on uniformity. 


\section{CONCLUSION}

The slopes oriented toward East with the elevation range between $250 \mathrm{~m}$ and $350 \mathrm{~m}$ and slope range from $10^{\circ}$ to $15^{\circ}$ or from $20^{\circ}$ to $25^{\circ}$ seem as the most susceptible for slope failures. The probability analysis showed the most dangerous areas. By this method, more than third of study area has high occurrence potentiality of landslides. However, the most important is relationship between line of road and landslides. The regression analysis showed clearly dependency of landslides on road. Videlicet, the landslides are equally distributed along the road. So, the main factor of occurrence landslides is not heavy rainfall, but anthropogenous intervention to the natural condition. The rainfall seems as only secondary factor and its function was as trigger which starts of shallow landslides.

\section{REFERENCES}

Ishikawa, E., 1964: Jitsumukuno tamero shintoukeigaku. Makishoten, Tokyo, Japan; p. 392.

Krcho, I. 1973: Morphometric analysis of relicf on the basis of geometric aspect of field theory. SPN, Acta [1, Geogr. Physica 1, Bratislava, Slovakia.

Krcho, J. 1990: Morfomelrická analýza a digitálne modely geo-rclićfu. VEDA. Bratislava, Slovakia; pp. 426.

Krcho, J. 1991: Georelief as subsystem of landscape and the influence of morphometric parameters of georelief on spatial differentiation of landscape-ecological processes. Fkologia, CSFR, 10; pp 115-157.

Mitášová, H., Hofierka, J., 1993: Interpolation by regularized spline with tension: II. Application to terrain modeling and surface geometry analysis. Mathematical Geology

Mitášová, H., Mitáš, L., 1993: Interpolation by regularized spline with tension: I. Theory and implementation. Mathematical Geology, 25. pp 641-655. 